\title{
Cassava Chip Drying by Using a Small-Scale Hot-Air Microwave Oven
}

\author{
Patomsok Wilaipon \\ Department of Mechanical Engineering, Naresuan University, Phitsanulok, Thailand
}

Received 2013-05-24, Revised 2013-06-04; Accepted 2013-06-06

\begin{abstract}
Characteristics of cassava microwave hot-air drying were investigated in a 2-planes microwave hot-air dryer. The drying experiments were carried out at two levels of sample surface temperature set-points viz. 70 and $80^{\circ} \mathrm{C}$ respectively. Cassava (Rayong-9) with $2.5 \mathrm{~kg}$ weight and $61 \%$ moisture content on wet basis was dried in the dryer for about 5-5.3 h. It was found that the drying time decreased with an increase in sample-surface temperature set point. Approximately $89 \%$ of the moisture was removed during the drying period. The rapid decrease in moisture ratio values followed by the gradual decline period was found in all experiments. With regard to drying kinetics, 5 commonly used mathematical models were examined with the experimental data. It was found that Page's and diffusion models provided a good agreement between the experimental and predicted moisture ratio values. The regression results indicated that high values of coefficient of determination and adjusted coefficient of determination as well as low value of standard error of estimation were reported for the case of these two models.
\end{abstract}

Keywords: Cassava Drying, Microwave, Drying

\section{INTRODUCTION}

Thermal drying may be defined as the process of thermally removing moisture to yield a solid product. Two processes simultaneously take place during thermal drying viz. the evaporation of surface moisture and the internal moisture transferring. The energy from the surrounding environment, as a result of convection, conduction, radiation, or the combination of these effects, is transferred to the drying product to evaporate the surface moisture. In addition, the movement of internal moisture to the surface of the drying product may occur through several mechanisms such as diffusion, capillary effect as well as an increase in internal pressure of the material.

According to the conventional hot-air dryer, several kinds of materials have been investigated with regard to their drying characteristics. Properties of dried poultry manure including its kinetics of thin layer drying, ranging from 1-3 cm, were studied by two researchers from Canada (Ghaly and Macdonald, 2012a; 2012b). In addition, some examples of fruits/vegetables drying characteristics namely Borneo Canarium Odontophyllum, tomato and lemon grass were also investigated (Basri et al., 2012; Brooks et al., 2008; Ibrahim et al., 2009).

One type of hot-air dryers for granular materials is the fluidized bed dryer, where the material is dried while suspended in the upward-flowing hot gas. Chili drying characteristics by using a continuous fluidized bed dryer, the kinetics of chili including the mathematical model of chili drying using a rotating fluidized bed technique were investigated by researchers from Thailand (Charmongkolpradit et al., 2010; Dongbang et al., 2010; Triratanasirichai et al., 2011). On the contrary to the hotair drying technique, freeze dried method offers the advantage of little loss of flavor and aroma. The moisture in the material is sublimated from the frozen material as a vapor in a vacuum chamber. Lime juice powder obtained from the vacuum freeze drying technique was an example of the researches (Theansuwan et al., 2008).

Another promising technique is microwave drying method, which is considerably different from the conventional drying. The electromagnetic field in microwave drying interacts with the drying material as a 
whole while the hot-air drying depends on the rate of heat propagation from higher-temperature material surface to the inside. Ozkan et al. (2007) investigated the drying characteristics of spinach using 8 microwave power levels. It was found that the drying process was completed between 290 to $4005 \mathrm{~s}$ depending on the value of microwave power. Microwave drying in combination with hot air drying was also used for pumpkin slices drying (Alibas, 2007). Drying periods for the case of microwave, hot air and combined microwave-air drying methods were studied. It was reported that the latter was accounted for the shortest drying period.

The aim of this study was to evaluate the drying characteristics of combined microwave-air method for the case of cassava. Furthermore, the mathematical model parameters were also calculated by using regression technique.

\section{MATERIALS AND METHODS}

\subsection{Material}

Rayong-9 cassavas with an initial moisture content of $61 \%$ on wet basis were obtained from a local factory in Phitsanulok, Thailand. Their initial moisture content value was examined, according to ASAE S358.2 DEC99 standard, by using a cabinet hot-air dryer (Memmert 600, $30-350^{\circ} \mathrm{C}, 2400 \mathrm{~W}$ ) and a digital balance (accuracy 0.001 $\mathrm{g})$. Then, the material was cut into $10 \mathrm{~mm}$ thick and 25-50 $\mathrm{mm}$ diameter with the cutting machine. All cassavas used in the experiment were from the same batch.

\subsection{Drying Experiment}

The drying system was comprised of two $86 \times 43 \mathrm{~mm}$ rectangular waveguides, two air-cooled magnetrons and a $44 \times 51 \times 93 \mathrm{~cm}$ cavity. Two $800 \mathrm{~W}$-magnetrons used in the experiments work at the frequency of $2.45 \mathrm{GHz}$. They were installed in the waveguides mounted on the top and the left of the cavity. Four heaters, $2 \mathrm{~kW}$ each, were installed at the air inlet duct. A temperature controller (Shimax MAC5D) and type K thermocouple were utilized for temperature control purpose. In order to record the sample weight loss, a $15 \mathrm{~kg}$ single-point load-cell coupled to a load cell indicator (Primus CM 013) was installed on the top of the cavity. Additionally, A Testo 435 , accuracy $\pm 0.25^{\circ} \mathrm{C}$ and $\pm 2 \%$ $\mathrm{RH}$, was used for measuring the temperature and relative humidity of inlet air.

In all experiments, approximately $2.5 \mathrm{~kg}$ of samples were used. The samples were uniformly spread on a drying tray and placed in the drying cavity. The temperature and velocity of hot air were set at $60^{\circ} \mathrm{C}$ and
$1 \mathrm{~m} \mathrm{sec}^{-1}$ respectively. A temperature sensor was utilized for measuring surface temperature of the sample. It was used as an input for microwave power operation control. The experiments were investigated at two levels of sample temperature viz 70 and $80^{\circ} \mathrm{C}$ respectively.

\subsection{Data Analysis}

The values of moisture ratio were calculated using the following Equation 1:

$$
\mathrm{MR}=\left(\mathrm{M}_{\mathrm{t}}-\mathrm{M}_{\mathrm{e}}\right) /\left(\mathrm{M}_{\mathrm{i}}-\mathrm{M}_{\mathrm{e}}\right)
$$

Where:

$\mathrm{MR}=$ The moisture ratio

$\mathrm{M}_{\mathrm{t}}=$ The moisture content at $1 \mathrm{~h} \mathrm{( \% )}$

$\mathrm{M}_{\mathrm{e}} \quad=$ The equilibrium moisture content (\%)

$\mathrm{M}_{\mathrm{i}}=$ The initial moisture content (\%)

Several conventional drying models have been proposed for determining the moisture ratio as a function of drying time. In this research, the drying models of cassava drying by using 2 planes magnetron microwaveair drying system were investigated. Newton model (Equation 2), Page's model (Equation 3), logarithmic model (Equation 4), Henderson\&Pabis model (Equation 5) and diffusion model (Equation 6) were applied to describe the characteristics of cassava drying:

$$
\begin{aligned}
& \mathrm{MR}=\exp (-\mathrm{kt}) \\
& \mathrm{MR}=\exp \left(-\mathrm{kt}^{\mathrm{n}}\right) \\
& \mathrm{MR}=(\mathrm{a}) \exp (-\mathrm{kt})+\mathrm{b} \\
& \mathrm{MR}=(\mathrm{a}) \exp (-\mathrm{kt}) \\
& \mathrm{MR}=(\mathrm{a}) \exp (-\mathrm{kt})(1-\mathrm{a}) \exp (-\mathrm{ktb})
\end{aligned}
$$

Where:

$$
\begin{array}{ll}
\mathrm{K} & =\text { The drying constant } \\
\mathrm{N} & =\text { The power parameter } \\
\mathrm{a} \text { and } \mathrm{b} & =\text { Parameters } \\
\mathrm{t} & =\text { Drying time (hour) }
\end{array}
$$

Coefficient of determination $\left(\mathrm{R}^{2}\right)$, adjusted coefficient of determination $\left(\mathrm{R}_{\text {adjusted }}^{2}\right)$ and Standard Error of Estimation (SEE) were utilized to evaluate the goodness of fit of the tested drying models to the experimental data. 


\section{RESULTS AND DISCUSSION}

Effective mathematical model of drying characteristic is crucial for cassava microwave-air drying kinetics investigation. The combination of microwave and hot-air energy was able to reduce the sample moisture content from 61 to $14 \%$ in $5-5.3 \mathrm{~h}$ depending on the levels of sample temperature set point. It was found that as the set-point temperature increased, the drying time was decreased. By using non-linear regression technique, the drying constants and coefficients of the five models obtained are shown in Table $\mathbf{1 .}$

In order to evaluate goodness of fit, coefficient of determination $\left(\mathrm{R}^{2}\right)$, adjusted coefficient of determination $\left(\mathrm{R}_{\text {adjusted }}^{2}\right.$ and Standard Error of Estimation (SEE) were also computed. The goodness of fit was determined by the higher $\mathrm{R}^{2}$ and $\mathrm{R}^{2}$ adjusted values as well as the lower SEE values. For all cases, it was found that $\mathrm{R}^{2}$ and

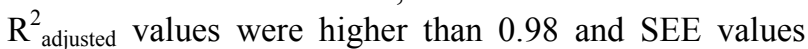
were lower than $3.1 \times 10^{-2}$.

Furthermore, it was found that diffusion and Page's models gave the excellent fit results for all the experimental data. For the case of diffusion model regression, the values of $\mathrm{R}^{2}, \mathrm{R}^{2}$ adjusted and SEE for 70$80^{\circ} \mathrm{C}$ set-point temperature were 0.9967-0.9989, 0.9962-0.9988 and 0.0101-0.0172 respectively. With regard to Page's model, the values of these three criteria were found to be $0.9957-0.9989,0.9954-$ 0.9988 and 0.0101-0.0189 respectively. Normal probability plots of residuals of these models are shown in Fig. 1-4.

Table 1. The drying constants and parameters of five drying models

\begin{tabular}{|c|c|c|c|c|}
\hline \multirow[b]{2}{*}{ Model } & \multicolumn{4}{|c|}{ The drying constants and coefficients } \\
\hline & $\mathrm{k}$ & $\mathrm{a}$ & $\mathrm{b}$ & $\mathrm{n}$ \\
\hline \multicolumn{5}{|l|}{ Newton } \\
\hline $80^{\circ} \mathrm{C}$ & 0.65787 & & & \\
\hline $70^{\circ} \mathrm{C}$ & 0.59300 & & & \\
\hline \multicolumn{5}{|l|}{ Page's } \\
\hline $80^{\circ} \mathrm{C}$ & 0.71960 & & & 0.85372 \\
\hline $70^{\circ} \mathrm{C}$ & 0.60304 & & & 0.97644 \\
\hline \multicolumn{5}{|c|}{ Logarithmic } \\
\hline $80^{\circ} \mathrm{C}$ & 0.73956 & 0.93514 & 0.04841 & \\
\hline $70^{\circ} \mathrm{C}$ & 0.58319 & 0.99553 & -0.00345 & \\
\hline \multicolumn{5}{|c|}{ Hendersonand Pabis } \\
\hline $80^{\circ} \mathrm{C}$ & 0.62955 & 0.96000 & & \\
\hline $70^{\circ} \mathrm{C}$ & 0.58903 & 0.99347 & & \\
\hline \multicolumn{5}{|c|}{ Diffusion } \\
\hline $80^{\circ} \mathrm{C}$ & 0.49012 & 0.69691 & 3.53314 & \\
\hline $70^{\circ} \mathrm{C}$ & 2.40151 & 0.03765 & 0.23877 & \\
\hline
\end{tabular}

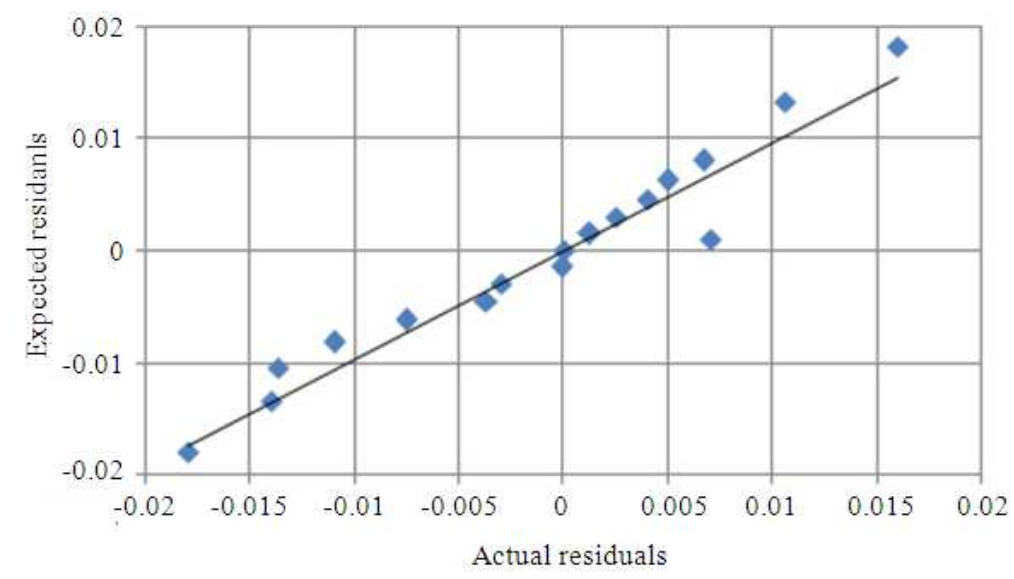

Fig. 1. Normal probability plot of residual of diffusion model for the case of $70^{\circ} \mathrm{C}$ 
Patomsok Wilaipon / American Journal of Engineering and Applied Sciences 6 (2): 211-215, 2013

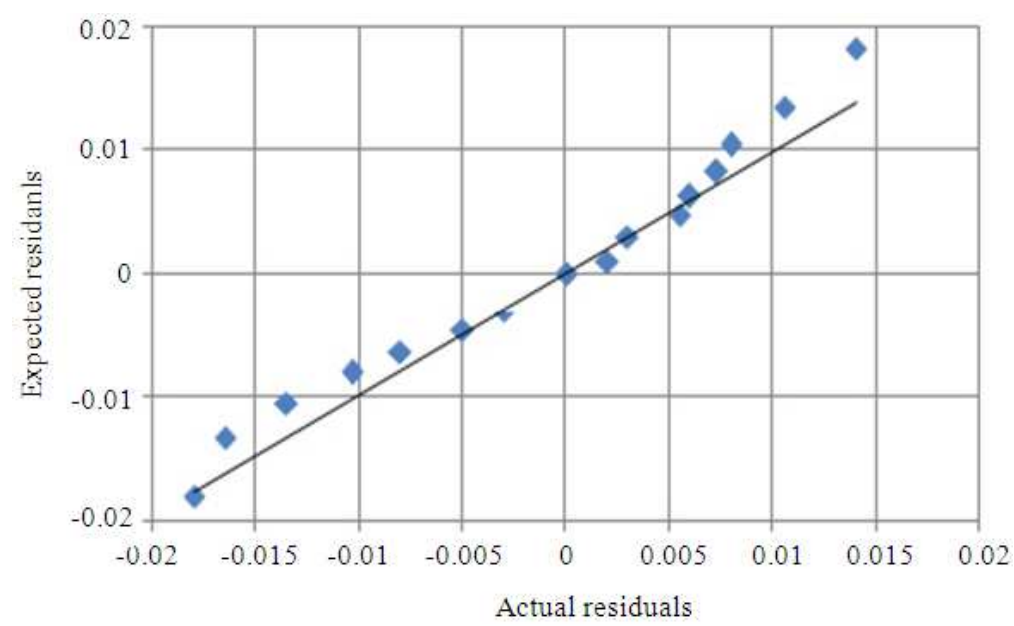

Fig. 2. Normal probability plot of residual of diffusion model for the case of $80^{\circ} \mathrm{C}$

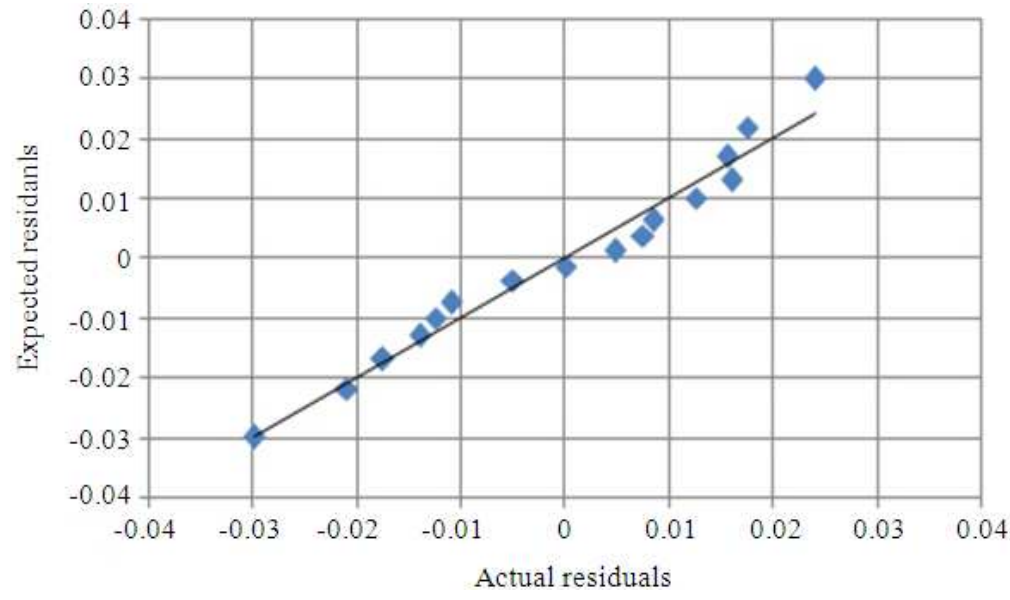

Fig. 3. Normal probability plot of residual of page's model for the case of $70^{\circ} \mathrm{C}$

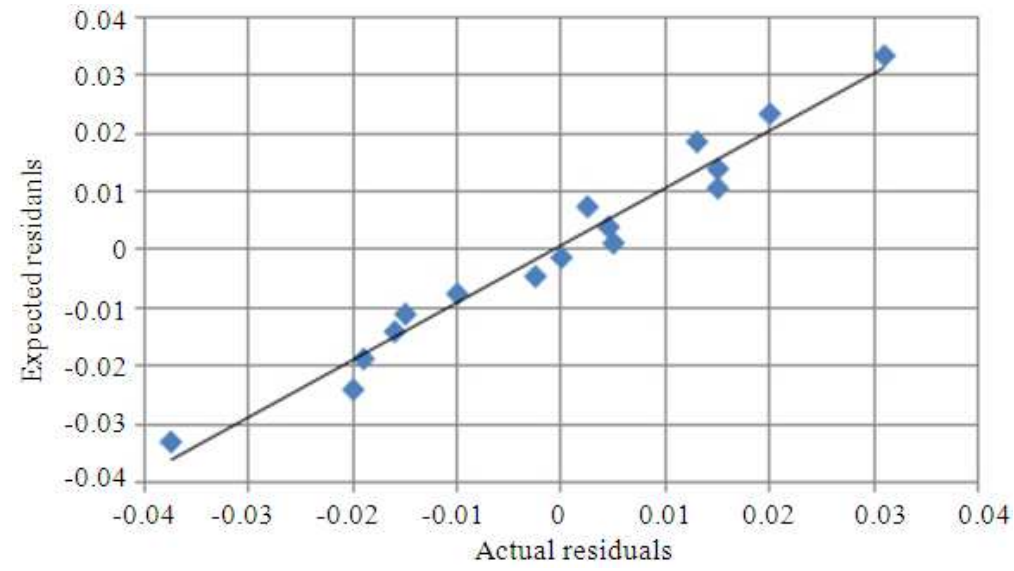

Fig. 4. Normal probability plot of residual of page's model for the case of $80^{\circ} \mathrm{C}$ 


\section{CONCLUSION}

Drying kinetic of cassava in a 2-planes microwave hot-air oven was investigated. Drying time decreased with an increase in sample-surface temperature set point. Approximately $89 \%$ of the moisture was removed from the sample during the 5-5.3 $\mathrm{h}$ drying-period. The rapid decrease in moisture ratio values followed by the gradual decline period was found in all experiments. With regard to 5 drying model applied to describe the drying kinetic of the sample, it was found that diffusion and Page's models provided a good agreement between the experimental and predicted moisture ratio values. High values of coefficient of determination and adjusted coefficient of determination as well as low value of standard error of estimation were also reported for the case of these two models.

\section{ACKNOWLEDGEMENT}

The author gratefully acknowledges Naresuan Univerity for the financial support and Energy for Environment Research Unit for the research equipment.

\section{REFERENCES}

Alibas, I., 2007. Microwave, air and combined microwave-air-drying parameters of pumpkin slices. Food Sci. Technol., 40: 1445-1451. DOI: 10.1016/j.lwt.2006.09.002

Basri, D.F., A. Fudholi and M.H. Rusian, 2012. Drying characteristics of the Borneo Canarium Odontophyllum (Dabai) fruit. Am. J. Agric. Biol. Sci., $\quad$ 7: 347-356. DOI: 10.3844/ajabssp.2012.347.356

Brooks, M.S., N.H.A. EI-Hana and A.E. Ghaly, 2008. Effects of tomato geometries and air temperature on the drying behavior of plum tomato. Am. J. Applied Sci., 5 : $1369-1375 . \quad$ DOI: 10.3844/ajassp.2008.1369.1375
Charmongkolpradit, S., K. Triratanasirichai and N. Srihajong, 2010. Drying characteristics of chili using continuous fluidized-bed dryer. Am. J. Applied Sci., 7: 1300-1304. DOI: 10.3844/ajassp.2010.1300.1304

Dongbang, W., W. Pirompugd and K. Triratanasirichai, 2010. The drying kinetics of chilies using a rotating fluidized bed technique. Am. J. Applied Sci., 7: 1599-1606. DOI: 10.3844/ajassp.2010.1599.1606

Ghaly, A.E. and K.N. MacDonald, 2012a. Drying of poultry manure for use as animal feed. Am. J. Agric. Biol. Sci., 7: 239-254. DOI: 10.3844/ajabssp.2012.239.254

Ghaly, A.E. and K.N. MacDonald, 2012b. Kinetics of thin layer drying of poultry manure. Am. J. Agric. Biol. Sci., 8: 128-142. DOI: 10.3844/ajbbsp.2012.128.142

Ibrahim, M., K. Sopian and W.R.W. Daud, 2009. Study of the drying kinetics of lemon grass. Am. J. Applied Sci., 6: 1070-1075. DOI: 10.3844/ajassp.2009.1070.1075

Ozkan, I.A., B. Akbudak and N. Akbudak, 2007. Microwave drying characteristics of spinach. J. Food Eng., 78: 577-583. DOI: 10.1016/j.jfoodeng.2005.10.026

Theansuwan, W., K. Triratanasirichai and K. Tangchaichit, 2008. Continuous production of lime juice by vacuum freeze drying. Am. J. Applied Sci., 5: 959-962. DOI: 10.3844/ajassp.2008. 959.962

Triratanasirichai, K., W. Dongbang and W. Pirompugd, 2011. Mathematical modeling of drying characteristics of chilies in a rotating fluidized bed technique. Am. J. Applied Sci., 8: 979-983. DOI: 10.3844/ajassp.2011.979.983 